\title{
Józef Maria Bocheński’s logical analyses of Question I of St. Thomas Aquinas' Summa Theologiae
}

\author{
Marek Porwolik
}

Published online: 10 September 2013

(C) The Author(s) 2013. This article is published with open access at Springerlink.com

\begin{abstract}
Bocheński claims that it would be very useful to apply logical tools to philosophical and theological investigations. His viewpoint can be ascribed to the fact that during Bocheński's youth logic and reflections on the foundations of mathematics flourished. His seminal work on these issues is the book Gottes Dasein und Wesen. Logische Studien zur Summa Theologiae I, qq. 2-11 (2003). Due to the fact that it was necessary to introduce numerous corrections to it, the book was published over a decade after submitting the manuscript to the publishing house in 1989 (according to certain sources, in 1991). There exist two manuscripts: one German (1989b) and one Polish (1993b). The latter contains also Bocheński's unpublished works, including the analyses of Question 1 from St. Thomas Aquinas' Summa Theologiae. In this Question, Aquinas focuses on the ways of understanding the term sacra doctrina. Bocheński's text, which is a logical analysis of that Question, seems to be almost completed. With reference to the topic and the method of analysis, the text constitutes a whole together with the analyses of Questions 2-11, published in Bocheński (2003).
\end{abstract}

Keywords Bocheński $\cdot$ St. Thomas Aquinas · Logic $\cdot$ Theology $\cdot$ Philosophy of God · Sacra doctrina · World-view

\section{Introduction}

It is impossible to talk about attempts to utilize logical tools in the philosophy of God without introducing the person and works of Fr. Józef Maria Bocheński (1902-1995). The inter-war period was the time of the activity of the so-called Cracow Circle. Besides Bocheński, the Circle included Fr. Jan Salamucha (1903-1944), Jan Franciszek Drewnowski (1886-1978), and Bolesław Sobociński (1906-1980). The Proof ex motu

M. Porwolik (ه)

Faculty of Christian Philosophy, Cardinal Stefan Wyszyński University in Warsaw, Warsaw, Poland e-mail: mapor3@wp.pl 
for the Existence of God. Logical Analysis of St. Thomas Aquinas' Arguments, a work whose author was Salamucha, and which was reviewed by Bocheński, became a turning point in the formation of the Circle. ${ }^{1}$ Salamucha's death in the Warsaw Uprising and the Bocheński's and Sobociński's emigration ended the official activity of the group. The person of Fr. Salamucha marked in a way the beginning and the end of the activity of the Cracow Circle. Bocheński returned to the interests of the school at the end of his life. The fruits of his return are the following works ${ }^{2}$ :

Ia J. M. Bocheński. Die fünf Wege. Freiburger Zeitschrift für Philosophie und Theologiae 36(1989) 3, 235-265;

Ib J. M. Bocheński. Pięć dróg. In: J. M. Bocheński, Logika i filozofia. Wybór pism. trans. J. Miziński, Warszawa: PWN, 1993, 469-503;

Ic J. M. Bocheński. The Five Ways. In: The Rationality of Theism, ed. by A. Garcia de la Sienra, Amsterdam-Atlanta: Rodopi, 2000, 61-92;

IIa J. M. Bocheński. Gottes Dasein und Wesen. Mathematisch-logische Studien zur Summa Theologiae I, qq. 2-13. Freiburg 1989, typescript;

IIb The typescript of the Polish translation of IIa, prepared by Bocheński in 1993 (no front page);

III J. M. Bocheński. Gottes Dasein und Wesen. Logische Studien zur Summa Theologiae I, qq. 2-11. München: Philosophia Verlag, 2003.

The pages of the works listed above include analyses aiming to realize the socalled program of the studies on God. Bocheński himself spoke about the need to formulate and realize such a program on October 15, 1990 when he was awarded the doctorate honoris causa at Warsaw Theological Academy. ${ }^{3}$ The program has the following form ${ }^{4}$ :

1. There is an urgent need to resume studies on God. ${ }^{5}$

2. A human being has only three ways of knowing God: direct experience, reasoning, and faith.

3. It is necessary to learn about the scholastic research into the issues connected with God.

4. The results of the scholastic doctrine of God should be judged critically.

5. An urgent task is to examine critically the Kantian and neo-positivist reservations concerning the possibility of knowing God, including the proofs of His existence. ${ }^{6}$

6. Looking at what an average believer's experience of God demonstrates gives rise to two tasks: (1) to determine what "experience" and similar words mean; (2) to examine how such experiences, in both the broad and the narrow senses, are possible, or if they really exist.

\footnotetext{
1 Salamucha (2003), [the original version: Salamucha (1934)].

2 On the left-hand side, the abbreviation used to refer to a given work has been provided.

3 Bocheński (1991).

4 Cf. IIa, 7-16; IIb, 2-9; III, 17-28.

${ }^{5}$ In IIb Bocheński adds that he means philosophical studies. Cf. IIb, 3.

${ }^{6}$ In IIb Bocheński is talking about the objections to the proofs of God's existence, and in IIa and III about the doubt about the possibilities of knowing God. Cf. IIb, 5 and 9; IIa, 11 and 16; III, 21-22 and 28.
} 
7. The scholastic doctrine of God should be studied with the tools of mathematics and logic as well as the critical method.

8. A believer does not need a proof of God's existence because he believes in this existence.

9. The type and the way of acceptance by a believer of God's existence requires detailed logical and theological studies.

10. It is necessary to develop a theology that is concerned first of all with God Himself.

For Bocheński, the main subject of the formal-logical research in the above program was St. Thomas Aquinas' Summa Theologiae. After a detailed analysis of Aquinas' text, Bocheński formalized Questions 2-11 and then, on the basis of the results, he presented the preliminary axiomatization of the theory of the Absolute. ${ }^{7}$ $\mathrm{He}$ also analysed the Kant's cosmological criticism of the argument for the existence of the Absolute. The results of these works were published in the book Gottes Dasein und Wesen. Logische Studien zur Summa Theologiae I, qq. 2-11 and can be found as well in the German and Polish manuscripts. In addition, the latter work contains the following texts: Wiara $i$ wiedza. Matematyczno-logiczny komentarz do pierwszego rozdziatu Sumy (Faith and Knowledge. A Mathematical-Logical Commentary to Chapter I of the Summa) and Powszechniki jako treści cech w filozofii św. Tomasza z Akwinu (Universals as the content of properties in St. Thomas Aquinas' Philosophy). ${ }^{8}$ Their absence from the other works can be explained by the fact that the Polish manuscript of the book dates from 1993 and constitutes the latest work of all the works in which the topic is discussed (with regard to the time of writing and editing by Bocheński). The German manuscript was sent to the publishing house in Munich either in 1990, as Hans Burkhardt writes in the introduction to the book, or in 1991, as Bocheński reports in the introduction to the Polish manuscript. ${ }^{9}$ Because Bocheński did not authorize the amendments introduced to the book by the publishing house, the Polish manuscript constitutes his latest text. It should be noted that the text we are interested in is not included in the introduction to the manuscript and in the table of contents. These two additional texts can be found in the manuscript following the list of contents. ${ }^{10}$ So far, they have not been published.

The aim of the present work is to carry out a critical analysis and reconstruction of the first of the above mentioned texts, that is, Bocheński's formalization of Question 1 of the Summa Theologiae. It can be useful in the future edition and publication of this study. Because Bocheński's text is not known to a wider public, it will be presented in detail so that the relevance of a commentary can be demonstrated. That is also why the character of the present study is descriptive rather than critical or polemical.

\footnotetext{
7 The formal analyses used by Bocheński are often called formalizations. By this is meant the translation of a text written in a natural language into a formal language. Cf. Ajdukiewicz (1978), (the original text: Ajdukiewicz (1934)).

${ }^{8}$ The translation is by the author of the present paper.

9 IIb, 1; III, 9.

${ }^{10} \mathrm{IIb}, 83-97 ; \mathrm{IIb}, 97-106$.
} 


\section{Bocheński's logical analyses}

Why did Bocheński actually undertake the logical analyses of Question I of St. Thomas Aquinas' Summa Theologiae? This question can be answered in the following way. First, such a study constitutes a whole together with Questions 2-11 which were analysed previously. Second, as the author emphasizes, although the fragment of the Summa describes the meaning of a very important term sacra doctrina (sacred doctrine), "in the writings on the topic we often encounter a mistake: either ignorance of this text or a hagiographical attitude towards the author who is treated like an infallible god." 11 According to Bocheński, what is required is an honest analysis.

The first problem he points to is the understanding of the expression sacra doctrina. In the first Article of the Question we are interested in finding arguments to show that the doctrine is indispensable for salvation, and in the second Article that the doctrine is a science. How should we understand the term then? Is it about faith or about theology? Bocheński claims that in both cases there is a contradiction. He shows it in the following way:

The abbreviations:

$$
\begin{aligned}
& \mathrm{dn}=: \text { sacred doctrine is indispensable for salvation, } \\
& \mathrm{ds}=: \text { sacred doctrine is a science, } \\
& \mathrm{fs}=: \text { faith is a science, } \\
& \text { tn }=: \text { theology is a science, } \\
& \text { ts }=: \text { theology is indispensable for salvation. }
\end{aligned}
$$

Bocheński tries to show the contradiction in the following way ${ }^{12}$ :

$\begin{array}{ll}\text { Article } 1 & \text { Article } 2 \\ \text { 1. ds } \rightarrow \text { ts } & 1^{\prime} \text {.dn } \rightarrow \text { fn } \\ \text { 2. dn } & 2^{\prime} . \mathrm{dn} \\ \text { 3. } \sim \text { ts } & 3^{\prime} \text {.fn }\end{array}$

from 1 and 2 by means of modus ponendo ponens we obtain:

$$
\text { 4. ts } \quad 4^{\prime} \text {.fn }
$$

and from 4 and 3 by means of conjunction introduction we obtain:

$$
\text { 5. ts } \wedge \sim \text { ts } \quad 5^{\prime} \text {. fn } \wedge \sim \text { fn }
$$

Thus, there is a contradiction.

Unfortunately, the above reconstruction is incomplete. There is no information about the meaning of the expression " $f n$ " which is used in the formalization referring to Article 2. Besides, verse 4 in the formalization of Article 1 does not result logically from verses 1 and 2, and the meanings of the expressions " $t n$ " and "fn" seem to be swapped ("n" means necessity and "s" means science).

Thus, Bocheński's idea can be reconstructed in the following way ${ }^{13}$ :

$11 \mathrm{IIb}, 83$. The translation is provided by the author of the present paper.

12 Here and throughout the paper we are using contemporary notation. The original one, used by Bocheński, comes from Whitehead and Russell's Principia Mathematica.

13 In order to differentiate the notation in the manuscript from its modification the latter is given in a box. 
Let us assume the following abbreviations:

$\mathrm{dn}=:$ sacred doctrine is indispensable for salvation,

ds =: sacred doctrine is a science,

$\mathrm{fn}=$ : theology is indispensable for salvation,

$\mathrm{fs}=$ : faith is a science,

tn =: theology is indispensable for salvation,

ts =: theology is a science.

Bocheński's formalizations can be presented in the following way:

$\begin{array}{ll}\text { Article } 1 & \text { Article } 2 \\ \text { 1. dn } \rightarrow \text { th } & 1^{\prime} \text {.ds } \rightarrow \text { fs } \\ \text { 2. dn } & 2^{\prime} \text {.ds } \\ \text { 3. } \sim \text { tn } & 3^{\prime} \text {. fs }\end{array}$

from 1 and 2 by means of modus ponendo ponens we obtain:

$$
\text { 4. th } \quad 4^{\prime} \text {. fs }
$$

and from 4 and 3 by means of conjunction introduction we obtain:

$$
\text { 5. th } \wedge \sim \text { th } \quad 5^{\prime} \text {. fs } \wedge \sim \text { fs }
$$

Thus, there is a contradiction.

There have been attempts to rescue the contradiction, as Bocheński writes. He points especially to the interpretation provided by Cajetan de Vio (1469-1534), who understands the term sacra doctrina as revealed knowledge either formaliter (literally), that is as faith, or virtualiter. Thus, it is neither faith only nor theology only. Bocheński makes references to the following text by Cajetan, taken from his commentary on Aquinas' Summa Theologiae ${ }^{14}$ :

1. ... dicendum est quod sacra doctrina neque sumitur pro fide, ut distinguitur contra theologiam; neque pro theologia, ut distinguitur contra fidem:

2. sed sumitur pro cognitione a Deo revelata sive formaliter, sive virtualiter,

3. ut habet rationem disciplinae et doctrinae, abstrahendo a ratione crediti et sciti.

4. Et quoniam cognitio hiuiusmodi ut disciplina est revelata, abstrahit a ratione credendi et sciendi,...

5. (ideo) ad nullum horum licet determinate descendere.

The above text is criticised by Bocheński, who introduces two additional abbreviations:

$\mathrm{f}=$ : sacred doctrine is faith,

$\mathrm{t}=$ : sacred doctrine is a (scientific) theology.

The main problem is the interpretation of the term abstrahit. It is translated as together. According to Bocheński, it refers to a logical sum. The same interpretation

\footnotetext{
14 Caietanus (1588).
} 
is suggested by the term sive in sentence $2 \mathrm{~b}$. If this is so, then, according to Bocheński, Cajetan assumes that:

$$
\begin{array}{ll}
\text { Article } 1 & \text { Article } 2 \\
1 . \mathrm{f} \vee \mathrm{t} \rightarrow \mathrm{tn} & 1^{\prime} \text {. } \mathrm{f} \vee \mathrm{t} \rightarrow \text { fs }
\end{array}
$$

but at the same time he claims that these sentences do not imply false sentences:

$$
2 . \mathrm{t} \rightarrow \mathrm{tn} \quad 2^{\prime} . \mathrm{f} \rightarrow \mathrm{fs} .
$$

As Bocheński observes, this is a mistake because the relevant directives of reasoning are correct. He uses the following schema of reasoning:

$$
\frac{\alpha \vee \beta \rightarrow \gamma}{\beta \rightarrow \gamma}
$$

The contradiction can be also avoided, according to Bocheński, not by rejecting but by accepting the content of relationship 2. This is the case because knowledge of scientific theology is indispensable for humanity as a whole, such that indirectly it is indispensable for each individual. Such an interpretation of Aquinas' text is common, although Bocheński does not find any real basis for it. Even if we accept this interpretation, sentence $2^{\prime}$ remains a false sentence.

The contradiction can also be avoided by assuming that, because in the Question under discussion the Bible is called scientia (science) by St. Thomas, the noun is used in a different sense than in the other texts. It is then possible to say that faith too is a science. However, such an interpretation is rejected by Bocheński. In his view, science means here an orderly set of sentences with axioms (principia), as defined by Aristotle. Besides, in such an interpretation of the term sacra doctrina it is impossible to understand it as a teaching activity. Bocheński notices also that the term appears four times in the discussed Question (3.2; 8.6; 9.3 and ad tertium), and it is equivalent to sacra scriptura. This equivalence is stated directly (2. ad 2: sacra Scriptura seu doctrina). It seems then that, according to Bocheński, the use of the term sacra doctrina is incoherent. It is not surprising that the term is also translated by means of the expression sacred science.

After conducting a critical review of Cajetan's commentary, Bocheński introduces his own analysis of the specific Articles of Question I of the Summa Theologiae. In order to do that he usually lists the abbreviations and inference rules used in the commented fragments.

The abbreviations:

$$
\begin{aligned}
& \mathrm{d}=: \text { Deus, } \\
& \mathrm{H}(\mathrm{x})=: \text { } x \text { est homo, } \\
& \mathrm{r}=: \text { revelata, } \\
& \mathrm{s}=: \text { sacra doctrina, } \\
& \mathrm{Sci}(\mathrm{x})=: \text { x est scientia }
\end{aligned}
$$

The directives of reasoning given by Bocheński include three rules of the logic of sentences, four non-syllogistic directives of first-order predicate calculus, and the

\footnotetext{
15 Bocheński notices that the name Deus can be treated here as an individual name rather than as a general one because of the direct references to Christianity. This fact simplifies the calculations. In the analyses of the following Questions of the Summa Theologiae we cannot understand that name in this way.

${ }^{16}$ In the third Article, a corresponding term revelabilia appears, which may lead to a certain ambiguity.
} 
syllogism Barbara, which is used in two versions. In the text under discussion, Acquinas uses this syllogism exceptionally frequently (according to Bocheński, in $70 \%$ of the verses in proofs). In the first version, the mood is used 8 times, in the other version it is used 9 times. ${ }^{17}$ Unfortunately, while listing the directives of the calculus of predicates, Bocheński commits mistakes in all four schemas. Nevertheless, they do not influence following the analyses. ${ }^{18}$

\begin{tabular}{|c|c|c|}
\hline The symbol & \multicolumn{2}{|c|}{ The form of the rule in the Predicate Calculus } \\
\hline \multirow[t]{2}{*}{$a$} & There is & 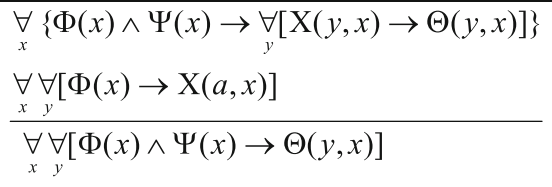 \\
\hline & There should be & 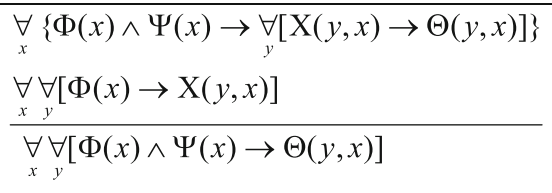 \\
\hline \multirow[t]{2}{*}{$b$} & There is & 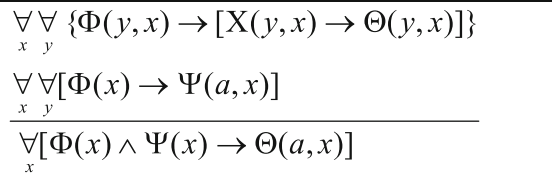 \\
\hline & There should be & $\begin{array}{l}\underset{x}{\forall} \underset{y}{\forall}\{\Phi(x) \wedge \Psi(x) \rightarrow[\mathrm{X}(y, x) \rightarrow \Theta(y, x)]\} \\
\underset{x}{\forall}[\Phi(x) \rightarrow \mathrm{X}(a, x)] \\
\underset{x}{\forall}[\Phi(x) \wedge \Psi(x) \rightarrow \Theta(a, x)]\end{array}$ \\
\hline \multirow[t]{2}{*}{$c$} & There is & $\frac{\underset{x}{\forall}[\Psi(y) \rightarrow \Psi(a, x)]}{\underset{x}{\forall}[\Phi(x) \rightarrow \underset{y}{\exists \Theta(y, x)]}}$ \\
\hline & There should be & $\frac{\underset{x}{\forall}[\Phi(x) \rightarrow \Psi(a, x)]}{\underset{x}{\forall}[\Phi(x) \rightarrow \underset{y}{\exists} \Psi(y, x)]}$ \\
\hline$d$ & There is & 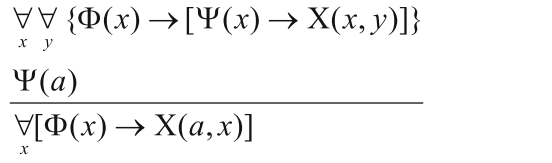 \\
\hline
\end{tabular}

${ }^{17}$ Bocheński claims that the Barbara mood is used 9 times in version I and 8 times in version II, which is a mistake. The total number of the verses in the proof is 24 . To make it more precise it is necessary to notice that these numbers come from what Bocheński wrote.

18 In the correction of the directives of reasoning only one of the many possible ways of reconstruction was presented. The goal was to make them correct from the perspective of logic. Another question is: what rules did Bocheński actually use? 
For the sake of the completeness of the analyses, let us provide the directives of the predicate calculus as well as the versions of the Barbara syllogism:

\begin{tabular}{|c|c|}
\hline $\begin{array}{l}\text { The symbol of the } \\
\text { rule }\end{array}$ & The form of the rule \\
\hline Ass & $\begin{array}{l}p \rightarrow q \\
\frac{p}{q}\end{array}$ \\
\hline Syll & $\begin{array}{l}p \rightarrow q \\
q \rightarrow r \\
p \rightarrow r\end{array}$ \\
\hline Transp & $\frac{\sim q \rightarrow \sim p}{p \rightarrow q}$ \\
\hline Barbara & $\begin{array}{l}\underset{x}{\forall}[\Phi(x) \rightarrow \Psi(x)] \\
\underset{x}{\forall[X(x) \rightarrow \Phi(x)]} \\
\underset{x}{\forall[X(x) \rightarrow \Psi(x)]}\end{array}$ \\
\hline Barbara 2-o & $\begin{array}{l}\forall\left[\begin{array}{l}\forall \\
x\end{array}\right. \\
\frac{\Phi(a)}{\Psi(a)}\end{array}$ \\
\hline
\end{tabular}

The simplicity of the above inference rules shows, according to Bocheński, the simplicity of reasoning in this part of the Summa.

Question 1 The Nature and Extent of Sacred Doctrine ${ }^{19}$

Article 1 Whether, besides philosophy, any further doctrine is required?

\begin{tabular}{|c|c|c|}
\hline Number & Latin & English \\
\hline 1.1. & $\begin{array}{l}\text {.. homo ordinatur ad Deum ad quendam } \\
\text { finem qui comprehensionem rationis } \\
\text { excedit, ... }\end{array}$ & $\begin{array}{l}\ldots \text { man is directed to God, as to an end that } \\
\text { surpasses the grasp of his reason: ... }\end{array}$ \\
\hline 1.2 . & $\begin{array}{l}\text { Finem autem oportet esse praecognitum } \\
\text { hominibus, qui suas intentiones et actiones } \\
\text { debent ordinare ad finem. }\end{array}$ & $\begin{array}{l}\text { But the end must first be known by men who } \\
\text { are to direct their thoughts and actions to the } \\
\text { end. }\end{array}$ \\
\hline 1.3 . & $\begin{array}{l}\text { Unde necessarium fuit homini ad salutem, } \\
\text { quod ei nota fierent quaedam per } \\
\text { revelationem divinam, ... }\end{array}$ & $\begin{array}{l}\text { Hence it was necessary for the salvation of } \\
\text { man that certain truths ... should be made } \\
\text { known to him by divine revelation. }\end{array}$ \\
\hline
\end{tabular}

\footnotetext{
19 The English text of the Summa comes from the following edition: Thomas Aquinas (2007). The Latin text used by Bocheński is taken from the following edition: Thomas Aquinas (1888).
} 


\begin{tabular}{|c|c|c|}
\hline Number & Latin & English \\
\hline 1.4. & $\begin{array}{l}\text { Quia veritas de Deo, per rationem } \\
\text { investigata, a paucis, et per longum } \\
\text { tempus, et cum admixtione multorum } \\
\text { errorum, homini proveniret: }\end{array}$ & $\begin{array}{l}\text {... because the truth about God such as reason } \\
\text { could discover, would only be known by a } \\
\text { few, and that after a long time, and with the } \\
\text { admixture of many errors. }\end{array}$ \\
\hline 1.5. & $\begin{array}{l}\text { a cuius tamen veritatis cognitione dependet } \\
\text { tota hominis salus, ... }\end{array}$ & $\begin{array}{l}\text { Whereas man's whole salvation, ..., depends } \\
\text { upon the knowledge of this truth. }\end{array}$ \\
\hline 1.6. & $\begin{array}{l}\text { Ut igitur salus hominibus et convenientius et } \\
\text { certius proveniat, necessarium fuit quod de } \\
\text { divinis per divinam revelationem } \\
\text { instruantur. }\end{array}$ & $\begin{array}{l}\text { Therefore, in order that the salvation of men } \\
\text { might be brought about more fitly and more } \\
\text { surely, it was necessary that they should be } \\
\text { taught divine truths by divine revelation. }\end{array}$ \\
\hline
\end{tabular}

The above text justifies the need to reveal the truths about God. Part I (1.1-1.3) concerns the truths that are inaccessible to natural cognition, and Part II (1.4-1.6) concerns the truths that are accessible to natural cognition. According to Bocheński, the content of the latter part is original and it constitutes St. Thomas' novelty, pointing to a kind of scepticism towards metaphysics.

Besides, Bocheński points to the fact that the name sacra doctrina is absent from corpus articuli. We only find it in the reply to the second objection. In this fragment there is also the term theologia. ${ }^{20}$ It is understood as a discipline whose only subject of study is the existence and the essence of God.

The above Article is reconstructed by Bocheński in the following way:

The abbreviations:

$\mathrm{cs}=$ : salus hominibus communius et securius provenit,

$\mathrm{EX}(\mathrm{x})=:$ excedit comprehensionem rationis,

$\mathrm{FN}(\mathrm{x}, \mathrm{y})=:$ : $x$ est finis $y$,

$\mathrm{OB}(\mathrm{x}, \mathrm{y})=:$ obtinetur $a b y$,

$\mathrm{PC}(\mathrm{x}, \mathrm{y})=:$ x praecognoscitur $a b y$,

$\mathrm{RV}(\mathrm{x}, \mathrm{y})=:$ : $x$ est notum de y per revelationem divinam,

$\mathrm{S}(\mathrm{x})=:$ salvatur.

Part one:

The premises:

$$
\begin{aligned}
& \text { 1. } \underset{x}{\forall}[H(x) \wedge S(x) \rightarrow P C(d, x)] \\
& \text { 2. } \underset{x}{\forall}[H(x) \rightarrow F N(d, x)] \\
& \text { 3. } \underset{x}{\forall} \forall\{P C(y, x) \rightarrow[E X(y, x) \rightarrow R V(y, x)]\} \\
& \text { 4. } \underset{x}{\forall}[H(x) \rightarrow E X(d, x)]
\end{aligned}
$$

According to Bocheński, the first and the third premises are obvious philosophical statements and for this reason they are considered to be analytical. The other premises are included in the Christian Credo. Next, Bocheński presents his proof.

\footnotetext{
20 "Theologia quae ad sacram doctrinam pertnet, differt secundum genus ab illa, quae pars philosophiae ponitur." ("Hence theology included in sacred doctrine differs inkind from that theology which is part of philosophy.").
} 
The proof:

$$
\begin{array}{lc}
\text { 5. } \underset{x}{\forall}[H(x) \wedge S(x) \rightarrow P C(d, x)] & 1,2, a \\
\text { 6. } \underset{x}{\forall}[H(x) \wedge S(x) \rightarrow R V(d, x)] & 3,4, b \\
\text { 7. } \underset{x}{\forall}[H(x) \wedge S(x) \rightarrow \underset{z}{\exists} R V(z, d)] & 6, c
\end{array}
$$

For Bocheński, the reasoning is progressive-deductive. He presumes also that for St. Thomas it was a kind of "reasoning in Barbara".

It is not difficult to notice that the above reconstructions contain numerous mistakes. For instance, verse 5 is a repetition of verse 1 (so verse 2 is unnecessary); in order to obtain verse 6 , verses 3 and 4 are insufficient, and in verse 7 the constant $d$ is provided instead of the variable $x$. Besides, in the formalization, the constant $d$ should appear in the right domain of the predicate $\mathrm{RV}(\mathrm{x}, \mathrm{y})$, and not in the left domain (according to the meaning of the abbreviation). We should also notice that the predicate $\mathrm{OB}(\mathrm{x}, \mathrm{y})$ from the list of abbreviations is absent from this formalization. Then, the predicate $\operatorname{EX}(x, y)$, which is present in the list of abbreviations in the formal reconstruction, is unary. Thus, we propose the following modification of Bocheński's formalization:

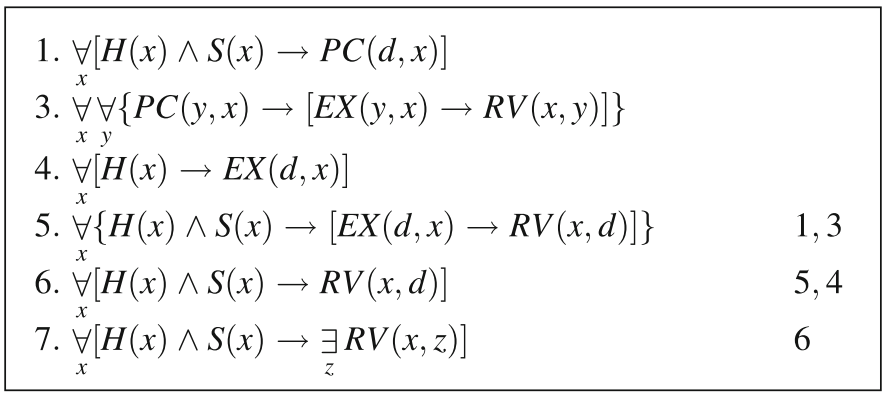

Thus, premise 2 is unnecessary in our reconstruction, and verses 5 and 6 follow in a way different from Bocheński's. When it comes to the predicate $\operatorname{EX}(\mathrm{x}, \mathrm{y})$, it can be understood in the following way:

\section{$\mathrm{EX}(\mathrm{x}, \mathrm{y})=:$ x excedit $y$ in comprehensionem rationis}

The second part is formalized by Bocheński as follows:

The premises:

$$
\begin{aligned}
& \text { 8. } \sim \underset{x}{\exists} R V(x, d) \rightarrow p r l \\
& \text { 9.prl } \rightarrow c s
\end{aligned}
$$

The proof:

$$
\begin{array}{ll}
\text { 10. } \sim \underset{x}{\exists} R V(x, d) \rightarrow \sim c s & 8,9, \text { Syll }, \\
\text { 11.cs } \rightarrow \underset{x}{\exists} R V(x, d) & \text { 10, Transp. }
\end{array}
$$

Here we can notice that there is no direct connection between parts one and two. Besides, Bocheński does not explain the abbreviation "prl". Noting the way 
the abbreviation "cs" is introduced we can understand it in the way presented below:

prl =: veritas de Deo per rationem investigata a paucis et per longum tempus, et cum admixtione multorum errorum homini proveniret

Thirdly, it should be noticed that verse 10 does not result from 8 and 9, which is the consequence of the lack of negation in the second argument of the implication in verse 9 . Thus, it should be:

\begin{tabular}{|c|c|}
\hline \multicolumn{2}{|l|}{ 8. $\sim \underset{x}{\exists} R V(x, d) \rightarrow p r l$} \\
\hline 10. $\sim \underset{x}{\exists} R V(x, d) \rightarrow \sim c s$ & 8,9, Syll \\
\hline 11. $c s \rightarrow \underset{x}{\exists} R V(x, d)$ & 10, Transp \\
\hline
\end{tabular}

\section{Question 1 The Nature and Extent of Sacred Doctrine}

Article $2 \quad$ Whether sacred doctrine is a science?

\begin{tabular}{|c|c|c|}
\hline Number & Latin & English \\
\hline 2.1. & ... duplex est scientiarum genus & $\ldots$ there are two kinds of sciences \\
\hline 2.2. & $\begin{array}{l}\text { Quaedam enim sunt, quae procedunt ex } \\
\text { principiis notis lumine naturali intellectus }\end{array}$ & $\begin{array}{l}\text { There are some which proceed from a } \\
\text { principle known by the natural light of } \\
\text { intelligence }\end{array}$ \\
\hline 2.3 . & sicut arithmetica, geometria et huiusmodi. & such as arithmetic and geometry and the like \\
\hline 2.4 . & $\begin{array}{l}\text { Quaedam vero sunt, quae procedunt ex } \\
\text { principiis notis lumine superioris scientiae }\end{array}$ & $\begin{array}{l}\text { There are some which proceed from } \\
\text { principles known by the light of a higher } \\
\text { science }\end{array}$ \\
\hline 2.5 . & $\begin{array}{l}\text { sicut perspectiva procedit ex principiis } \\
\text { notificatis per geometriam, et musica ex } \\
\text { principiis per arithmeticam notis }\end{array}$ & $\begin{array}{l}\text { thus the science of perspective proceeds from } \\
\text { principles established by geometry, and } \\
\text { music from principles established by } \\
\text { arithmetic }\end{array}$ \\
\hline 2.6. & Et hoc modo sacra doctrina est scientia & So it is that sacred doctrine is a science \\
\hline 2.7. & $\begin{array}{l}\text { quia procedit ex principiis notis lumine } \\
\text { superioris scientiae }\end{array}$ & $\begin{array}{l}\text { because it proceeds from principles } \\
\text { established by the light of a higher science }\end{array}$ \\
\hline 2.8. & quae scilicet est scientia Dei et beatorum & namely, the science of God and the blessed \\
\hline 2.9. & $\begin{array}{l}\text { Unde sicut musica credit principia tradita sibi } \\
\text { ab arithmetico, ita doctrina sacra credit } \\
\text { principia revelata sibi a Deo }\end{array}$ & $\begin{array}{l}\text { Hence, just as the musician accepts on } \\
\text { authority the principles taught him by the } \\
\text { mathematician, so sacred science is } \\
\text { established on principles revealed by God }\end{array}$ \\
\hline
\end{tabular}

Bocheński claims that this Article is the most important one in Question I. It points to the difference between faith and knowledge and gives the first known relativization of the notion of the scientific system. In Aquinas' time, on the basis of Posterior Analytics, science or knowledge, described with the Greek term $\varepsilon \pi \imath \sigma \tau \varepsilon \mu \eta$ was the deductive system based on obvious axioms; everything else was $\delta o \xi \alpha$, mere opinion. 
Bocheński points to the fact that as knowledge of the Posterior Analytics grew Christians faced the task of determining the relationships between scientific methodology and the Christian faith. They did this in various ways. Bocheński reminds us that St. Peter Damiani (1007-1072) rejected Aristotle's treatise, judging it to be a work by Satan. St. Anselm (1033-1109) considered it possible to prove the content of faith on the basis of the principles of reasoning. St. Thomas chose none of these ways. He claimed that although the content of faith cannot be proven, sacred doctrine is a science. For the sake of this claim, Aquinas changed the meaning of the term axiom. It was no longer necessary for the axiom to be obvious for everyone. It was enough when it was obvious for God and the saved people (the saints). From this viewpoint, theology remains a science despite the fact that not all its axioms are obvious for everyone. Bocheński notices also that the term lumen naturalis intellectus (verse 2.2) is used in contrast to the direct intellectual insight, and not to revelation. This is proven by verse 2.5 .

The abbreviations:

$\mathrm{Ks}(\mathrm{x})=: x$ is a knowledge obtained by deduction,

$\operatorname{Sci}(\mathrm{x})=: x$ is a science

The premises:

$$
\begin{aligned}
& \text { 1. } \underset{x}{\forall}[K s(x) \rightarrow S c i(x)] \\
& \text { 2. } K s(s)
\end{aligned}
$$

The deduction ${ }^{21}$ :

$$
\text { 3. } \operatorname{Sci}(s) \quad \text { 1, 2, Barbara 2-o }
$$

\begin{tabular}{|c|c|c|}
\hline Number & Latin & English \\
\hline 3.1 . & $\begin{array}{l}\text { Est enim unitas potentiae et habitus } \\
\text { consideranda secundum obiectum, non } \\
\text { quidem materialiter, sed secundum rationem } \\
\text { formalem obiecti: ... }\end{array}$ & $\begin{array}{l}\text { The unity of a faculty or habit is to be gauged } \\
\text { by its object, not indeed, in its material } \\
\text { aspect, but as regards the precise formality } \\
\text { under which it is an object }\end{array}$ \\
\hline 3.2 . & $\begin{array}{l}\text { Quia igitur sacra scriptura considerat aliqua } \\
\text { secundum quod sunt divinitus revelata, ... }\end{array}$ & $\begin{array}{l}\text { Therefore, because Sacred Scripture } \\
\text { considers things precisely under the } \\
\text { formality of being divinely revealed }\end{array}$ \\
\hline 3.3. & $\begin{array}{l}\text { omnia quaecumque sunt divinitus revelabilia, } \\
\text { communicant in una ratione formali obiecti } \\
\text { huius scientiae }\end{array}$ & $\begin{array}{l}\text { whatever has been divinely revealed } \\
\text { possesses the one precise formality of the } \\
\text { object of this science }\end{array}$ \\
\hline 3.4 . & $\begin{array}{l}\text { Et ideo comprehenduntur sub sacra doctrina } \\
\text { sicut sub scientia una }\end{array}$ & $\begin{array}{l}\text { and therefore is included under sacred } \\
\text { doctrine as under one science }\end{array}$ \\
\hline
\end{tabular}

Question 1 The Nature and Extent of Sacred Doctrine

Article $3 \quad$ Whether sacred doctrine is one science?

\footnotetext{
${ }^{21}$ In this place Bocheński usually uses the term proof. The term deduction is also used in articles 7 and 8 of the discussed Question.
} 
When analysing this fragment, Bocheński notices that in sentence 3.1 the expression potentiae et habitus is understood as a type of mental disposition (meaning is subjective) and not as a set of sentences (the objective meaning). Besides, he claims that verse 3.2 is unnecessary in the entire process of reasoning, and the term sciptura should be replaced by the term doctrina. It is impossible to agree totally with Bocheński because premise 3 in his formalization is based on this very verse. In another terminological remark he refers to verse 3.3. Instead of revelabilia it is better to use revelata. Otherwise, theology would be a universal science covering everything.

The abbreviations:

$\mathrm{Crr}(\mathrm{x})=:$ x considerat aliquem secundum quod sunt revelata, ${ }^{22}$

$\operatorname{Cur}(\mathrm{x})=:$ x considerat aliquem secundum unam rationem,

$\mathrm{Us}(\mathrm{x})=:$ est una scientia.

The premises:

$$
\begin{aligned}
& \text { 1. } \underset{x}{\forall}[\operatorname{Cur}(x) \rightarrow U s(x)] \\
& \text { 2. } \underset{x}{\forall}[\operatorname{Crr}(x) \rightarrow \operatorname{Cur}(x)] \\
& \text { 3. } \operatorname{Crr}(s)
\end{aligned}
$$

The proof:

$$
\begin{aligned}
& \text { 4. } \underset{x}{\forall}[\operatorname{Crr}(x) \rightarrow U s(x)] \\
& \text { 5. } U s(s)
\end{aligned}
$$

\begin{tabular}{|c|c|c|}
\hline Number & Latin & English \\
\hline 4.1. & $\begin{array}{l}\text {... sacra doctrina,..., una existens, se extendit } \\
\text { ad ea quae pertinent ad diversas scientias } \\
\text { philosophicas }\end{array}$ & $\begin{array}{l}\text {.. Sacred doctrine, being one, extends to } \\
\text { things which belong to different } \\
\text { philosophical sciences }\end{array}$ \\
\hline 4.2 . & $\begin{array}{l}\text { propter rationem formalem quam in diversis } \\
\text { attendit: ... }\end{array}$ & $\begin{array}{l}\text { because it considers in each the same formal } \\
\text { aspect, ... }\end{array}$ \\
\hline 4.3 . & prout sunt divino lumine cognoscibilia & $\begin{array}{l}\text { so far as they can be known through divine } \\
\text { revelation }\end{array}$ \\
\hline 4.4 . & $\begin{array}{l}\text { Unde licet in scientiis philosophicis alia sit } \\
\text { speculativa et alia practica }\end{array}$ & $\begin{array}{l}\text { Hence, although among the philosophical } \\
\text { sciences one is speculative and another } \\
\text { practical }\end{array}$ \\
\hline 4.5 . & $\begin{array}{l}\text { Sacra tamen doctrina comprehendit sub se } \\
\text { utramque; ... }\end{array}$ & $\begin{array}{l}\text { Nevertheless sacred doctrine includes both; } \\
\ldots\end{array}$ \\
\hline 4.6. & Magis tamen est speculativa quam practica & Still, it is speculative rather than practical \\
\hline 4.7. & $\begin{array}{l}\text { quia principalius agit de rebus divinis quam de } \\
\text { actibus humanis; ... }\end{array}$ & $\begin{array}{l}\text { because it is more concerned with divine } \\
\text { things than with human acts; } \ldots\end{array}$ \\
\hline
\end{tabular}

4, 3, Barbara 2-o

\section{Question 1 The Nature and Extent of Sacred Doctrine \\ Article $4 \quad$ Whether sacred doctrine is a practical science?}

\footnotetext{
22 In the list of abbreviations given by Bocheński there is the predicate $\mathrm{Cr}(\mathrm{x})$, but in the formalization of this Article and the following Article $\operatorname{Crr}(\mathrm{x})$ is used. We assume that it is the result of a spelling mistake.
} 
According to Bocheński, the above Article consists of two fragments. The first (4.1-4.5) shows that sacred doctrine is a theoretical and practical discipline, and the second (4.6-4.7) emphasizes the primary character of the previous claim. Doctrina sacra understood in this way means theology, not faith.

The abbreviations:

$\mathrm{Ah}(\mathrm{x})=:$ sunt actus humani, ${ }^{23}$

$\operatorname{Cop}(\mathrm{x})=:$ considerat obiecta scientiarum practicarum prout sunt cognoscibilia lumine divino,

$\operatorname{Cos}(\mathrm{x})=:$ considerat obiecta scientiarum speculativarum prout sunt congnoscibilia lumine divino,

$\mathrm{Cr}(\mathrm{x})=:$ considerat aliqua secundum quod sunt revelata,

$\operatorname{Mgs}(\mathrm{x})=:$ x est magis speculativa quam practica,

$\mathrm{Nsi}(\mathrm{x})=:$ est naturale $x$ ut per sensibilia ad intellgibilia venat,

$\operatorname{PRA}(\mathrm{x}, \mathrm{y}, \mathrm{z})=: x$ principalius agit de y quam de $\mathrm{z}$,

$\mathrm{Rd}(\mathrm{x})=:$ sunt res divinae,

$\mathrm{Spr}(\mathrm{x})=:$ x est scientia practica,

$\mathrm{Ssp}(\mathrm{x})=:$ est scienta speculativa.

Part one:

The premises:

$$
\begin{aligned}
& \text { 1. } \underset{x}{\forall}[\operatorname{Crr}(x) \rightarrow \operatorname{Cos}(x) \wedge \operatorname{Cop}(x)] \\
& \text { 2. } \underset{x}{\forall}[\operatorname{Cos}(x) \wedge \operatorname{Cop}(x) \rightarrow \operatorname{Ssp}(x) \wedge \operatorname{Spr}(x)] \\
& \text { 3. } \operatorname{Crr}(s)
\end{aligned}
$$

The proof:

$$
\begin{array}{ll}
\text { 4. } \underset{x}{\forall}[\operatorname{Crr}(x) \rightarrow \operatorname{Ssp}(x) \wedge \operatorname{Spr}(x)] & \text { 1, 2, Barbara } \\
\text { 5. } \operatorname{Ssp}(s) \wedge \operatorname{Spr}(s) & \text { 4, 3, Barbara 2-o }
\end{array}
$$

Part two:

The premises:

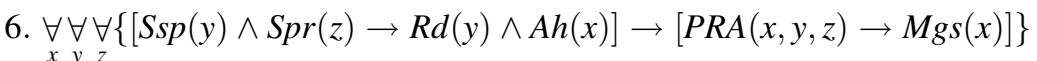

7. $\underset{y}{\forall} \underset{z}{\forall}[R d(y) \wedge A h(z) \rightarrow \operatorname{PRA}(s, y, z)]$

The proof:

$$
\begin{array}{ll}
\text { 8. } \underset{y}{\forall} \forall\{[R d(y) \wedge A h(z) \rightarrow P R A(s, y, z)] \rightarrow \operatorname{Mgs}(x)\} & \text { 6, 5, Barbara 2-o } \\
\text { 9. } \operatorname{Mgs}(s) & 8,7, \text { Barbara }
\end{array}
$$

Bocheński notices that, as in the case of the previous Article, only the Barbara syllogism was used in the reconstruction. Because the formalization of the second part contains small mistakes (premise 6 is rather controversial, and apart from that verses 8 and 9 do to result from the verses presented by Bocheński in the way he

\footnotetext{
${ }^{23}$ In the list of abbreviations there is the predicate $\mathrm{AH}(\mathrm{x})$, but $\mathrm{Ah}(\mathrm{x})$ is used in the formalization.
} 
suggests), this fragment needs to be reconstructed. In order not to distort the original formulae we suggest the following modification:

The premises:

6. $\underset{x}{\forall} \underset{y}{\forall} \underset{z}{\forall}\{\operatorname{Ssp}(x) \wedge \operatorname{Spr}(x) \rightarrow[[R d(y) \wedge A h(z) \rightarrow \operatorname{PRA}(x, y, z)] \rightarrow \operatorname{Mgs}(x)]\}$

7. $\underset{y}{\forall} \underset{z}{\forall}[R d(y) \wedge A h(z) \rightarrow P R A(s, y, z)]$

The proof:

$$
\begin{array}{ll}
\text { 8. } \underset{y}{\forall z} \forall\{R d(y) \wedge A h(z) \rightarrow P R A(s, y, z)] \rightarrow \operatorname{Mgs}(s)\} & 6,5 \\
\text { 9. } \operatorname{Mgs}(s) & 8,7, \text { Ass }
\end{array}
$$

\section{Question 1 The Nature and Extent of Sacred Doctrine \\ Article $5 \quad$ Whether sacred doctrine is nobler than other sciences?}

Number Latin English

5.1. $\quad \ldots$ ista scientia..., omnes alias transcendit...

5.2. Speculativarum enim scientiarum una altera dignior dicitur, tum propter certitudinem, tum propter dignitatem materiae

5.3. Et quantum ad utrumque, haec scientia alias speculativas scientias excedit

5.4. Secundum certitudinem quidem

5.41. quia aliae scientiae certitudinem habent ex naturali lumine rationis humanae

5.42. quae potest errare

5.43. haec autem certitudinem habet ex lumine divinae scientiae

5.44. quae decipi non potest

5.5. Secundum dignitatem vero materiae

5.51. quia ista scientia est principaliter de his quae sua altitudine rationem transcendunt

5.52. aliae vero scientiae considerant ea tantum quae rationi subduntur

5.6. Practicarum vero scientiarum illa dignior est, quae ad ulteriorem finem ordinatur, ...

5.7. Finis autem huius doctrinae inquantum est practica, est beatitudo aeterna

5.8. ad quam sicut ad ultimum finem ordinantur omnes alii fines scientiarum practicarum

5.9. Unde manifestum est, secundum omnem modum, eam digniorem esse allis
... this science ... transcends all others ...

Now one speculative science is said to be nobler than another, either by reason of its greater certitude, or by reason of the higher worth of its subject-matter

In both these respects this science surpasses other speculative sciences

in point of greater certitude

because other sciences derive their certitude from the natural light of human reason

which can err

whereas this derives its certitude from the light of divine knowledge

which cannot be misled

in point of the higher worth of its subjectmatter

because this science treats chiefly of those things which by their sublimity transcend human reason

while other sciences consider only those things which are within reason's grasp

Of the practical sciences, that one is nobler which is ordained to a further purpose, ...

But the purpose of this science, in so far as it is practical, is eternal bliss

to which as to an ultimate end the purposes of every practical science are directed

Hence it is clear that from every standpoint, it is nobler than other sciences 
Bocheński points to the precision and beauty of this Article. St. Thomas shows in it that sacred doctrine is more dignified than all the other theoretical and practical sciences. Bocheński tries to present the structure of the discussed Article in the following way:

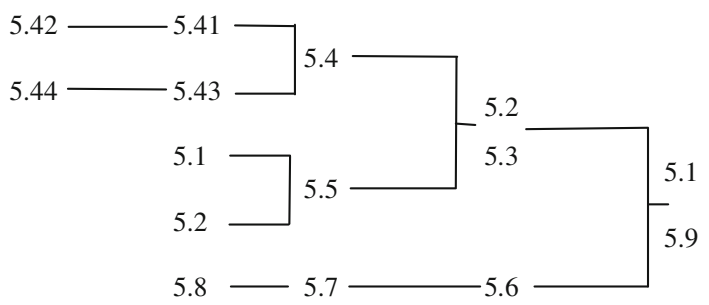

Because of some visible inaccuracies in the above schema we suggest a small modification:

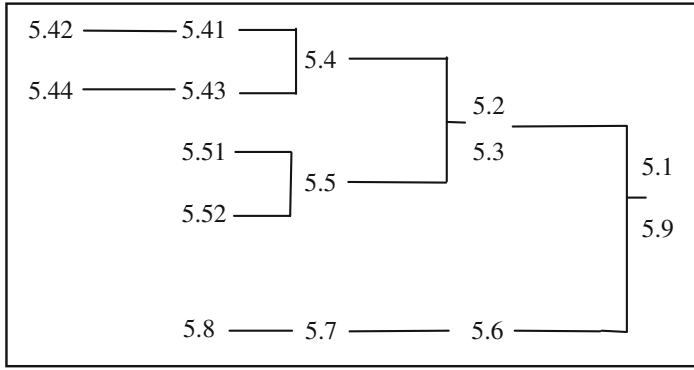

Bocheński remarks (as seen also in the above schema) that St. Thomas' reasoning in this Article is virtually only regressive.

The abbreviations:

$\mathrm{CE}(\mathrm{x}, \mathrm{y})=:$ est certior $y$,

$\mathrm{Cld}(\mathrm{x})=:$ xabet certitudinem ex lumine divino, ${ }^{24}$

$\operatorname{Cop}(\mathrm{x})=: x$ considerat obiecta scientiarum practicarum prout sunt congnosci-

bilia lumine divino,

$\operatorname{DG}(\mathrm{x}, \mathrm{y})=:$ est dignior $y$,

$\mathrm{FN}(\mathrm{x}, \mathrm{y})=:$ est finis $y$,

$\operatorname{Spr}(\mathrm{x})=:$ est scientia practica,

$\mathrm{Ssp}(\mathrm{x})=:$ est scienta speculativa,

$\mathrm{Ulf}(\mathrm{x}, \mathrm{y})=:$ est ulterior $y^{25}$

Part one:

\footnotetext{
${ }^{24}$ In the original version, there is $\mathrm{Cld}(\mathrm{s})$ on the left-hand side of the equation, which we treat as an obvious mistake.

25 In the list of abbreviations there is only the predicate $\operatorname{ULf}(\mathrm{x}, \mathrm{y})$, but in the formalization there is Ulf(x,y). If we want to be faithful to Bocheński's way of creating abbreviations, we should use the predicate Ult $(\mathrm{x}, \mathrm{y})$ here.
} 
The premises:

$$
\begin{aligned}
& \text { 1. } \underset{x}{\forall y}\{\{[\sim \operatorname{Cld}(x) \wedge \operatorname{Ssp}(x) \rightarrow \operatorname{Cld}(y)] \rightarrow C E(y, x)\} \\
& \text { 2. } \underset{x y}{\forall} \forall[C E(y, x) \rightarrow D G(y, x)] \\
& \text { 3. } C l d(s) \\
& \text { 4. } \underset{x}{\forall}\{[\sim(x=s) \wedge \operatorname{Ssp}(x)] \rightarrow[\sim \operatorname{Cld}(x) \wedge \operatorname{Ssp}(x)]\} \\
& \text { 5. } \underset{x}{\forall} \forall[\operatorname{Ulf}(x, y) \rightarrow D G(x, y)] \\
& \text { 6. } \underset{x}{\forall}[\sim(x=s) \wedge \operatorname{Ssp}(\sigma) \rightarrow \operatorname{Ulf}(x, y)]
\end{aligned}
$$

The $\operatorname{proof}^{26}$ :

$$
\begin{array}{ll}
\text { 7. } \underset{x}{\forall} \forall\{[C l d(x) \wedge S s p(x)] \rightarrow[C l d(y) \rightarrow D G(y, x)]\} & 1,2, \text { Barbara } \\
\text { 8. } \underset{x}{\forall}\{[\sim C l d(x) \wedge S s p(x)] \rightarrow D G(s, x)\} & 7,3, d \\
\text { 9. } \underset{x}{\forall}\{[\sim(x=s) \wedge S s p(x)] \rightarrow D G(s, x)\} & 8,4, \text { Barbara }
\end{array}
$$

The form of premise 1 provided above raises numerous controversies. Besides, it is easily noticeable that verse 6 is totally unnecessary and obscure (because of the use of the constant/variable $\sigma){ }^{27}$ Verse 7 does not result from verses 1 and 2 on the basis of the Barbara syllogism (even if the lack of the symbol of negation in the first element of the antecedent of the formula in verse 7 is taken into account), and verse 8 does not result from verses 7 and 3 on the basis of the $d$ schema. Besides, the predicate Cop(x) is absent from the formal reconstruction, although it appears in the list of abbreviations. There is also no recollection of the way of understanding the predicate $\mathrm{OB}(\mathrm{x}, \mathrm{y})$. Perhaps in this place the formalization should take the following shape:

The premises:

$$
\begin{aligned}
& \text { 1. } \underset{x y}{\forall} \forall\{[\sim \operatorname{Cld}(x) \wedge S s p(x)] \rightarrow[\operatorname{Cld}(y) \rightarrow C E(y, x)]\} \\
& \text { 2. } \underset{x \quad y}{\forall}[\operatorname{CE}(y, x) \rightarrow D G(y, x)] \\
& \text { 3. } \operatorname{Cld}(s) \\
& \text { 4. } \underset{x}{\forall}\{[\sim(x=s) \wedge \operatorname{Ssp}(x)] \rightarrow[\sim \operatorname{Cld}(x) \wedge \operatorname{Ssp}(x)]\} \\
& \text { 5. } \underset{x}{\forall} \forall[\operatorname{Ulf}(x, y) \rightarrow D G(x, y)]
\end{aligned}
$$

The proof:

$$
\begin{array}{ll}
\text { 7. } \underset{x}{\forall} \forall\{[\sim C l d(x) \wedge S s p(x)] \rightarrow[C l d(y) \rightarrow D G(y, x)]\} & 1,2 \\
\text { 8. } \underset{x}{\forall}\{[\sim C l d(x) \wedge S s p(x)] \rightarrow D G(s, x)\} & 7,3 \\
\text { 9. } \underset{x}{\forall}\{[\sim(x=s) \wedge S s p(x)] \rightarrow D G(s, x)]\} & 8,4, \text { Barbara }
\end{array}
$$

\footnotetext{
26 This is a slight modification of the Barbara syllogism (verse 7).

27 Probably it was supposed to take the following shape: $\underset{x}{\forall}[\sim(x=s) \wedge S s p(x) \rightarrow U l f(s, x)]$.
} 


\section{Part two:}

The premises:

$$
\begin{aligned}
& \text { 10. } \underset{x}{\forall} \underset{y}{\forall} \underset{z}{\forall} \forall\{[[[O B(z, x) \rightarrow O B(t, y)] \rightarrow \operatorname{Ulf}(z, t)] \rightarrow[\operatorname{Spr}(y) \rightarrow D G(x, y)]\} \\
& \text { 11. } \forall \forall \forall\{[O B(z, s) \rightarrow O B(t, y)] \rightarrow \operatorname{Ulf}(z, t)\}
\end{aligned}
$$

The proof $^{28}$ :

$$
\text { 12. } \underset{y}{\forall}[\operatorname{Spr}(y) \rightarrow D G(s, y)] \quad \text { Barbara 2-o }
$$

Obviously, it is possible to formalize the second part of the Article in a different way, in order to avoid the propositions that $U l f(d, d)$ or $D G(s, s)$, which can be done, for instance, in the following way:

The premises:

10. $\forall \forall \forall \forall\{[\operatorname{Spr}(x) \wedge \operatorname{Spr}(y) \wedge O B(z, x) \wedge O B(t, y)] \rightarrow[\operatorname{Ulf}(z, t) \rightarrow D G(x, y)]\}$

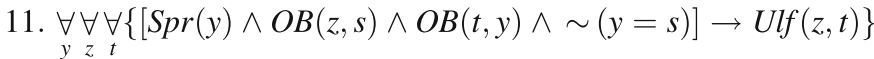

$11^{\prime} . \operatorname{Spr}(s)$

The proof:

12. $\left.\underset{y z_{t}}{\forall \forall\{} \forall[\operatorname{Spr}(y) \wedge O B(z, s) \wedge O B(t, y) \wedge \sim(y=s)] \rightarrow D G(s, y)\right\} \quad 10,11,11^{\prime}$

\section{Question 1 The Nature and Extent of Sacred Doctrine}

Article $6 \quad$ Whether this doctrine is the same as wisdom?

Number Latin English

6.1. $\quad \ldots$ ille sapiens dicitur in unoquoque genere, qui considerat causam altissimam illius generis

6.2. Ille igitur qui considerat simpliciter altissimam causam totius universi, quae Deus est, maxime sapiens dicitur: ...

6.3. Sacra autem doctrina propriissime determinat de Deo, secundum quod est altissima causa: ...

6.4. Unde sacra doctrina maxime dicitur sapientia
... he is said to be wise in any one order who considers the highest principle in that order: ...

Therefore he who considers absolutely the highest cause of the whole universe, namely God, is most of all called wise

But sacred doctrine essentially treats of God viewed as the highest cause ...

Hence sacred doctrine is especially called wisdom

In the commentary to this fragment Bocheński points to two issues. First, sacred doctrine, according to Aquinas, is wisdom in the highest degree (not only wisdom), and apart from that, he talks about it in 6.1-6.2, when describing a wise man, and not wisdom itself.

\footnotetext{
28 Although not stated by Bocheński, verses 10 and 11 are meant here. The presented inference rule is not the one that is actually used.
} 
The abbreviations:

$\operatorname{Ac}(\mathrm{x})=:$ x est altissima causa,

$\mathrm{OB}(\mathrm{x}, \mathrm{y})=:$ obtinetur $a b y$,

$\mathrm{Sm}(\mathrm{x})=:$ x est maxime sapientia.

The premises:

$$
\begin{aligned}
& \text { 1. } \underset{x}{\forall} \forall\left\{\begin{array}{l}
\forall \\
\text { 2. } O B(d, x) \rightarrow[A c(y) \rightarrow S m(x)]\} \\
\text { 3. } A c(d)
\end{array}\right.
\end{aligned}
$$

The proof ${ }^{29}$ :

$$
\begin{array}{ll}
\text { 4. } A c(d) \rightarrow \operatorname{Sm}(s) & \text { 1, 2, Barbara 2-o } \\
\text { 5. } \operatorname{Sm}(s) & \text { 4, 3, Ass }
\end{array}
$$

\begin{tabular}{|c|c|c|}
\hline Number & Latin & English \\
\hline 7.1. & ... Deus est subiectum huius scientiae & $\ldots$ God is the object of this science \\
\hline 7.2 . & $\begin{array}{l}\text { Proprie autem illud assignatur obiectum } \\
\text { alicuius potentiae vel habitus, sub cuius } \\
\text { ratione omnia referuntur ad potentiam vel } \\
\text { habitum }\end{array}$ & $\begin{array}{l}\text { Now properly speaking, the object of a } \\
\text { faculty or habit is the thing under the aspect } \\
\text { of which all things are referred to that } \\
\text { faculty or habit, ... }\end{array}$ \\
\hline 7.3. & $\begin{array}{l}\text { Omnia autem pertractantur in sacra doctrina } \\
\text { sub ratione Dei: ... }\end{array}$ & $\begin{array}{l}\text { But in sacred science, all things are treated of } \\
\text { under the aspect of God: ... }\end{array}$ \\
\hline
\end{tabular}

\section{Question 1 The Nature and Extent of Sacred Doctrine}

Article $7 \quad$ Whether God is the object of this science?

The abbreviations:

$\mathrm{OB}(\mathrm{x}, \mathrm{y})=:$ : $x$ est obiectum $y$,

$\mathrm{REF}(\mathrm{x}, \mathrm{y}, \mathrm{z})=:$ refertur in $y$ sub ratione $z$.

The premises:

$$
\begin{aligned}
& \text { 1. } \underset{x}{\forall} \forall \underset{z}{\forall}[\operatorname{REF}(x, y, z) \rightarrow O B(z, y)] \\
& \text { 2. } \underset{x}{\forall R E F(x, s, d)}
\end{aligned}
$$

The deduction ${ }^{30}$ :

$$
\text { 3. } O B(d, s) \quad 1,2, \text { Barbara 2-o }
$$

It is necessary to notice the different understanding of the predicate $\mathrm{OB}(\mathrm{x}, \mathrm{y})$ from the one in the previous Articles (where it was an abbreviation for $x$ obtinetur $a b y$ ). Obviously, in this case it is possible to ask if it is the same relationship but

29 Here we deal with a slight modification of the syllogism Barbara 2-o.

30 The inference rule used here is different from Barbara 2-o. 
expressed by means of a different Latin term. Besides, because of Aquinas' text certain doubts are raised by premise 1 . We suggest the following modification:

The premises:

$$
\begin{aligned}
& \text { 1. } \forall \forall[\forall R E F(x, y, z) \rightarrow O B(z, y)] \\
& \text { 2. } \forall \operatorname{REF}(x, s, d)
\end{aligned}
$$

The deduction:

$$
\text { 3. } O B(d, s) \quad 1,2
$$

\section{Question 1 The Nature and Extent of Sacred Doctrine}

Article $8 \quad$ Whether sacred doctrine is a matter of argument?

Number Latin English

8.1. $\quad \ldots$ sicut aliae scientiae non argumentantur ad sua principia probanda

8.2. sed ex principiis argumentantur ad ostendendum alia ...

8.3. ita haec doctrina non argumentatur ad sua principia probanda, quae sunt articuli fidei

8.4. $\quad$ sed ex eis procedit ad aliquid aliud ostendendum; ...

8.5. Sed tamen... suprema... (scientia) scilicet metaphysica, disputat contra negantem sua principia, ...

8.6. Unde sacra scriptura, cum non habeat superiorem, disputat cum negante sua principia:...
English

... As other sciences do not argue in proof of their principles

but argue from their principles to demonstrate other truths ...

so this doctrine does not argue in proof of its principles, which are the articles of faith

but from them it goes on to prove something else; ...

However, it is to be borne in mind, ... the highest ... (science), viz. metaphysics, can dispute with one who denies its principles,

Hence Sacred Scripture, since it has no science above itself, can dispute with one who denies its principles...

Bocheński emphasises that this fragment includes the following claims:

1. Sacred doctrine does not prove its principia (8.3).

2. Sacred doctrine proves sentences deduced from its own assumptions (8.4).

3. Sacred doctrine uses proofs against people who deny these assumptions (8.6).

St. Thomas justifies these sentences by analogy with other sciences. The third claim is compared to metaphysics. In this Article, sacra doctrina is clearly shown as a science in the full Aristotelian meaning of this word. When it comes to the terminology used, Bocheński notices that the term sacra scriptura appears here in the sense of sacred doctrine.

The abbreviations:

$\operatorname{Af}(x)=: x$ est articulus fide ,

$\operatorname{Di}(\mathrm{x})=: x$ disputat cum negante sua principia,

$\operatorname{PRi}(\mathrm{x}, \mathrm{y})=:$ : $x$ est principium $y$, 
$\operatorname{PRo}(\mathrm{x}, \mathrm{y})=:$ probatur $a b y,{ }^{31}$

$\operatorname{Sci}(\mathrm{x})=:$ est scientia,

$\mathrm{Ss}(\mathrm{x})=:$ $x$ est suprema scientia.

The premises:

$$
\begin{aligned}
& \text { 1. } \underset{x}{\forall} \forall[\operatorname{PRi}(x, y) \rightarrow \sim \operatorname{PRo}(x, y)] \\
& \text { 2. } \underset{x}{\forall}[\operatorname{Af}(x) \rightarrow \operatorname{PRi}(x, s)] \\
& \text { 3. } \underset{x}{\forall}\{\operatorname{Sci}(x) \rightarrow \underset{y}{\exists}[\sim \operatorname{PRi}(y, x) \wedge \operatorname{PRo}(x, y)]\} \\
& \text { 4. } \operatorname{Sci}(s) \\
& \text { 5. } \underset{x}{\forall}[\operatorname{Ss}(x) \rightarrow \operatorname{Di}(x)] \\
& \text { 6. } S s(s)
\end{aligned}
$$

The deduction:

$$
\begin{array}{ll}
\text { 7. } \underset{x}{\forall} \forall[\operatorname{Af}(x) \rightarrow \sim \operatorname{PRo}(x, s)] & 1,2 \text {, Barbara } \\
\text { 8. } \underset{y}{\exists}[\sim \operatorname{PRi}(y, s) \wedge \operatorname{PRo}(s, y)] & 3,4, \text { Barbara } 2-o \\
\text { 9.Di(s) } & 5,6, \text { Barbara 2-o }
\end{array}
$$

As we can see, in Bocheński's formalization it is enough to have verses 5 and 6 to obtain verse 9 (likewise, to obtain verse 8 it is enough to have verses 3 and 4 ). The other verses are not used to obtain the final conclusion, unless we assume that the final conclusion is what verses 7 , 8 and 9 present together. Besides, in verse 3, in the predicate $\operatorname{PRo}(\mathrm{x}, \mathrm{y})$ the order of the variables should be reversed. In verse 7 it is unnecessary to quantify the variable $y$. Because of these remarks the formal reconstruction should include the following corrections:

The premises:

$$
\begin{aligned}
& \text { 1. } \underset{x}{\forall} \underset{y}{\forall}[\operatorname{PRi}(x, y) \rightarrow \sim \operatorname{PRo}(x, y)] \\
& \text { 2. } \underset{x}{\forall}[\operatorname{Af}(x) \rightarrow \operatorname{PRi}(x, s)] \\
& \text { 3. } \underset{x}{\forall}\{\operatorname{Sci}(x) \rightarrow \underset{y}{\exists}[\sim \operatorname{PRi}(y, x) \wedge \operatorname{PRo}(y, x)]\} \\
& \text { 4. } \operatorname{Sci}(s) \\
& \text { 5. } \underset{x}{\forall}[\operatorname{Ss}(x) \rightarrow \operatorname{Di}(x)] \\
& \text { 6. } \operatorname{Ss}(s)
\end{aligned}
$$

The deduction:

$$
\begin{array}{ll}
\text { 7. } \underset{x}{\forall}[\operatorname{Af}(x) \rightarrow \sim \operatorname{PRo}(x, s)] & 1,2 \\
\text { 8. } \underset{y}{\exists}[\sim \operatorname{PRi}(y, s) \wedge \operatorname{PRo}(y, s)] & 3,4, \text { Barbara } 2-o \\
\text { 9. } \operatorname{Di}(s) & \text { 5, 6, Barbara 2-o }
\end{array}
$$

\footnotetext{
31 In the list of abbreviations there are the predicates Pri(x,y) and $\operatorname{Pro}(\mathrm{x}, \mathrm{y})$, but in the formalization there are $\operatorname{PRi}(\mathrm{x}, \mathrm{y})$ and $\operatorname{PRo}(\mathrm{x}, \mathrm{y})$. In order to obtain a homogeneous notation we accept the latter forms.
} 


\section{Question 1 The Nature and Extent of Sacred Doctrine}

Article 9 Whether Holy Scripture should use metaphors?

\begin{tabular}{|c|c|c|}
\hline Number & Latin & English \\
\hline 9.1. & $\begin{array}{l}\text { Est autem naturale homini ut per sensibilia ad } \\
\text { intelligibilia veniat }\end{array}$ & $\begin{array}{l}\text { Now it is natural to man to attain to } \\
\text { intellectual truths through sensible objects }\end{array}$ \\
\hline 9.2 . & $\begin{array}{l}\text { quia omnis nostra cognitio a sensu initium } \\
\text { habet }\end{array}$ & $\begin{array}{l}\text { because all our knowledge originates from } \\
\text { sense }\end{array}$ \\
\hline 9.3 . & $\begin{array}{l}\text { Unde convenienter in sacra Scriptura } \\
\text { traduntur nobis spiritualia sub metaphoris } \\
\text { corporalium }\end{array}$ & $\begin{array}{l}\text { Hence in Holy Writ, spiritual truths are } \\
\text { fittingly taught under the likeness of } \\
\text { material things }\end{array}$ \\
\hline 9.4. & $\begin{array}{l}(\text { ad } 1 \text {-um }) \ldots \text { sacra doctrina utitur metaphoris } \\
\text { propter necessitatem et utilitatem, ... }\end{array}$ & $\begin{array}{l}\text { (Reply to Objection 1) But sacred doctrine } \\
\text { makes use of metaphors as both necessary } \\
\text { and useful }\end{array}$ \\
\hline 9.5 & $\begin{array}{l}\text { (ad 2-um) ... quae in uno loco Scripturae } \\
\text { traduntur sub metaphoris, in aliis locis } \\
\text { expressius exponuntur }\end{array}$ & $\begin{array}{l}\text { (Reply to Objection } 2) \ldots \text { those things that } \\
\text { are taught metaphorically in one part of } \\
\text { Scripture, in other parts are taught more } \\
\text { openly }\end{array}$ \\
\hline
\end{tabular}

Bocheński remarks that the terms sacra scriptura and sacra doctrina are used interchangeably here (verses 9.3, 9.4, 9.5). The former expression seems to be more appropriate here.

The abbreviations:

Cis $(\mathrm{x})=$ : cognitio $x$ initium habet a sensibus,

$\mathrm{M}(\mathrm{x})=$ : convenienter in sacra Scriptura traduntur $x$ spiritualia sub metaphoris corporalium,

$\mathrm{Nsi}(\mathrm{x})=:$ est naturale $x$ ut per sensibilia ad intellgibilia veniat.

The premises:

$$
\begin{aligned}
& \text { 1. } \underset{x}{\forall}[\operatorname{Cis}(x) \rightarrow \operatorname{Nsi}(x)] \\
& \text { 2. } \underset{x}{\forall}[\operatorname{Nsi}(x) \rightarrow M(x)] \\
& \text { 3. } \underset{x}{\forall}[H(x) \rightarrow \operatorname{Cis}(x)]
\end{aligned}
$$

The proof:

$$
\begin{array}{ll}
\text { 4. } \underset{x}{\forall}[\operatorname{Cis}(x) \rightarrow M(x)] & 1,2, \text { Barbara } \\
\text { 5. } \underset{x}{\forall}[H(x) \rightarrow M(x)] & 4,3, \text { Barbara }
\end{array}
$$

\section{Question 1 The Nature and Extent}

Article 10 Whether in Holy Scripture a word may have several senses?

Here, Bocheński only makes the comment that the text is exegetic and refers to Holy Scripture, not to sacred doctrine. 
Bocheński's concludes his analyses with a comparison of the Thomistic theory of faith and the contemporary theory of the world-view. The most import differences are as follows:

1. Religious faith is the only world-view known in the Middle Ages. The present notion of the world-view is a generalization and secularization of the notion used in the Middle Ages. The notion consists of the synthesis of a subject's knowledge, answers to existential questions, and moral code.

2. In the Middle Ages, people did not differentiate between faith and knowledge.

3. It was accepted in those times that a sentence needed to be deduced from obvious premises in order for it to be a scientific claim.

Bocheński presents the obtained results in the following way:

\begin{tabular}{|c|c|}
\hline The Thomistic theory of faith & The contemporary theory of the world-view \\
\hline $\begin{array}{l}\text { It is possible to know God, the ultimate goal of } \\
\text { one's life by means of reason only }\end{array}$ & $\begin{array}{l}\text { Science is incapable of answering the existential } \\
\text { questions about the sense of life }\end{array}$ \\
\hline $\begin{array}{l}\text { Even what can be learned about God by reason } \\
\text { only is learned by only a few people; it is also } \\
\text { time-consuming and not flawless }\end{array}$ & Metaphysics is a very difficult discipline \\
\hline $\begin{array}{l}\text { In order to achieve his goal, a man needs } \\
\text { revelation, that is faith }\end{array}$ & $\begin{array}{l}\text { The answer to the most important questions can } \\
\text { only be given by a world-view }\end{array}$ \\
\hline $\begin{array}{l}\text { The content of faith cannot be proven; faith must } \\
\text { be accepted by means of a free decision }\end{array}$ & $\begin{array}{l}\text { The content of a world-view cannot be proven } \\
\text { and must be accepted by means of a free } \\
\text { decision }\end{array}$ \\
\hline $\begin{array}{l}\text { The axioms of theology are not obvious for us } \\
\text { (although they are obvious for God) }\end{array}$ & Axioms of theoretical sciences are not obvious \\
\hline Despite that, theology can be a science & $\begin{array}{l}\text { Despite that, systems based on such axioms can } \\
\text { be scientific }\end{array}$ \\
\hline
\end{tabular}

Bocheński's analyses cease, or rather are interrupted here. There is no broader summary although it was typical of Bocheński to prepare one. The absence of a summary concerns, for instance, the matter of relationships in the conceptual net constituted by the notions sacra doctrina, knowledge, theology, religious faith, and world-view, as well as assumptions used throughout. The impression that the work was unfinished remains despite the fact that on the last page (p. 97) the next unpublished text begins, titled Powszechniki jako treści cech w filozofii św. Tomasza $z$ Akwinu (Universals as the content of properties in St. Thomas Aquinas' Philosophy).

\section{Conclusions}

Despite the rough character of Bocheński's text it deserves appreciation for the following reasons:

1. It is the first attempt to formalize Question I of St. Thomas Aquinas' Summa Theologiae. 
2. It constitutes a whole (with regard to the subject and the method of analysis) with the published commentaries on Questions 2-11 of the Summa Theologiae.

3. After introducing certain necessary corrections, the material prepared by Bocheński can be the starting point for creating a formal theory of the notion sacra doctrina.

4. Bocheński's formalizations have contributed to the precision of the notions present in the discussed Question.

5. Connecting the notions appearing in the analysed Question with the notion of the contemporary world-view is both bold and revealing.

6. Bocheński skillfully identified the chains of reasoning in St. Thomas' text and reconstructed them in a formal way.

It seems that Bocheński's analyses were nearly completed. The main question that arises in regard to them is: how to understand the term sacra doctrina, used by Aquinas? After identifying the difficulties and the ways used previously to overcome them, Bocheński suggests his own solutions. The key issue seems to be the notion of the religious world-view. Bocheński claims that it is a generalization of the theory of faith presented by St. Thomas. Thus, the Articles of Question I are a description of what can be named the religious world-view today. However, Bocheński does not provide anywhere in the text the answer to the question: how to solve the problems encountered in Question I of the Summa Theologiae in case the term doctrina sacra is understood in this way? In the formal analyses we have discussed we also find a surprising, for Bocheński, role assigned to formalizations. In the case of quinque viae they allowed Bocheński to assess the value of Aquinas' particular arguments; in the case of the formalizations of the following Questions of the Summa Theologiae they permitted him to identify the most appropriate description of the Absolute and to create the preliminary axiomatization of the theory of the Absolute. When it comes to the first Question, the formal relationships seem to play a secondary role. The final conclusion claiming that we are dealing here with a world-view, results from the content of this Question, but is not connected directly to the formalizations. We need to admit that the reconstruction of St. Thomas Aquinas' reasoning in a formal language and the demonstration of its correctness are valuable results, but in our case, this does lead to the final conclusion, which shows the similarities between the theory of faith presented by St. Thomas and the contemporary theory of the world-view. A number of questions resulting from this problem remain unanswered.

The formal anlyses of Question I of the Summa Theologiae conducted by Bocheński are an insightful and scrupulous study carried out with the use of formal logic. The study has a final conclusion. Nevertheless, the work seems unfinished. This offers encouragement to continue investigations in line with Bocheński's ideas. Let us hope that this encouragement will be answered properly by those who cherish both theology and logic.

Open Access This article is distributed under the terms of the Creative Commons Attribution License which permits any use, distribution, and reproduction in any medium, provided the original author(s) and the source are credited. 


\section{References}

Ajdukiewicz, K. (1934). O stosowalności czystej logiki do zagadnień filozoficznych. Przeglad Filozoficzny, 37, 323-327.

Ajdukiewicz, K. (1978). On the applicability of pure logic to philosophical problems. In K. Ajdukiewicz (Ed.), The scientific world-perspective and other essays, 1931-1963 (pp. 90-94). Dordrecht/Boston: Reidel.

Bocheński, J. M. (1989a). Die fünf Wege. Freiburger Zeitschrift für Philosophie und Theologiae, 36(3), 235-265.

Bocheński, J. M. (1989b). Gottes Dasein und Wesen. Mathematisch-logische Studien zur Summa Theologiae I, qq. 2-13. Freiburg: Typescript.

Bocheński, J. M. (1991). O współczesnym stanie i zadaniach teologii filozoficznej (On the contemporary state and tasks of theology). Studia Philosophiae Christianae, 27(2), 103-107.

Bocheński, J. M. (1993a). Pięć dróg (The five ways). In: J. M. Bocheński (Ed.), Logika i filozofia. Wybór pism (pp. 469-503) (trans: Miziński, J.). Warszawa: PWN.

Bocheński, J. M. (1993b). Gottes Dasein und Wesen. Mathematisch-logische Studien zur Summa Theologiae I, qq. 2-13. Freiburg, the typescript of the Polish translation prepared by Bocheński (no front page).

Bocheński, J. M. (2000). The five ways. In A. Garcia de la Sienra (Ed.), The rationality of theism (pp. 61-92). Amsterdam-Atlanta: Rodopi.

Bocheński, J. M. (2003). Gottes Dasein und Wesen. Logische Studien zur Summa Theologiae I, qq. 2-11. München: Philosophia Verlag.

Caietanus, Thomas de Vio (1588). Summa totius theologiae S. Thomae de Aquino. Venetiis.

Salamucha, J. (1934). Dowód na istnienie Boga. Analiza logiczna argumentacji św. Tomasza z Akwinu. Collectanea Theologica, 15, 53-92.

Salamucha, J. (2003). The proof ex motu for the existence of God. Logical analysis of St. Thomas Aquinas' arguments. In J. Salamucha (Ed.), Knowledge and faith (pp. 97-135). Amsterdam, NY: Rodopi (Translation of Salamucha, J. (1934)).

Thomas Aquinas, (1888). Thomae Aquinatis Opera omnia (Ed. Leonina). Vol. 4, Romae.

Thomas Aquinas, (2007). Summa Theologica trans: Fathers of the English Dominican Province, Vol. 1, New York: Cosimo. 